\section{Dietary management of diabetic children}

Sir,

We wish to comment on the article by Birkbeck, Truswell, and Thomas, "Current practice in dietary management of diabetic children', and to report briefly our experience in Belgium.

We agree with the authors that it is illogical to limit carbohydrate intake. The consequences are higher fat intake and an increased risk of vascular complications. In Belgium we teach diabetic children the principles of a diet deriving its calories as follows: $12-15 \%$ protein, $30-35 \%$ lipid, and 50-55\% carbohydrate (Ernould et al., 1973; Dorchy et al., 1975). These calories are divided into 3 principal meals and 3 snacks varying with the activity of the child as well as with the type of insulin used. The dose of insulin is adapted to the results of four daily analyses with Clinitest 2/10 (Dorchy and Loeb, 1975).

Nevertheless, we have observed, in two dietetic investigations made during a summer camp for diabetic adolescents, an abnormally high proportion of lipid (Mozin et al., 1975, 1976). The relative values of intakes were proteins $12 \cdot 68 \% \pm 1 \cdot 60$, lipids $41 \cdot 58 \% \pm 4 \cdot 12$, carbohydrates $45 \cdot 73 \% \pm 3 \cdot 87$. This is probably the result of Belgian dietary habits. Indeed this is not the case in France where the same dietary management is practiced. French diabetic children of $\mathrm{H}$. Lestradet* consume $20-30 \%$ of their calories from lipids and 55$60 \%$ from carbohydrates (Dartois and Lestradet, 1966; Lestradet et al., 1974). We must therefore concintrate our efforts on emphasizing fat rather than carbohydrate restriction.

In our study we noted considerable daily variations in total calories (2411-4289 kcal; 10-18 MJ), lipids (85$186 \mathrm{~g})$, carbohydrates $(307-490 \mathrm{~g})$, and proteins (77-127 g). These very significant individual variations in food intake have not brought about a proportional modification in insulin requirements, glucosuria, or urine volume, as shown by a covariance analysis (Mozin et al., 1976). It is essential that diabetic children themselves adjust their daily caloric intake after their individual appetites. Children do not have fixed caloric requirements, because they are growing and show variable physical activity.

Imposing a weighed and measured diet is of no real benefit. A restricted diet that controls only carbohydrate intake and thus favours fat intake is potentially dangerous to the vascular system. A total caloric restriction inhibits growth. Moreover, the notion of 'measuring' leads to rejection of the entire therapeutic regimen and to emotional problems. In addition, the percentage of retinopathies that occur in relation to the duration of diabetes in children on a spontaneously balanced and adapted diet compares favourably with those occurring on the restricted diet (Lestradet and Billaud, 1968; François, 1976).

*Pioneer of the spontaneously balanced diet-now accepted by the majority of the paediatricians in the world-and president of the International Study Group for Diabetes in Children and Adolescents.
The goal in the therapy of diabetic children is to avoid the appearance of diabetic angiopathy by maintaining the highest possible degree of control (i.e. lowest glucosuria, normal blood lipids, and normal growth) (Dorchy et al., 1976; Drash, 1976; Ernould et al., 1976). This is obtained through appropriate insulin therapy and adequate distribution of food intake but not through dietetic restrictions.

\section{H. DORCHY and H. LOEB Diabetic Unit, Department of Paediatrics, University of Brussels, Rue Haute 320, B-1000 Brussels, Belgium.}

Professor J. A. Birkbeck replies as follows:

Drs. Dorchy and Loeb's comments regarding their observations in Belgium and France are a valuable addition to our paper. In view of the individual variation in timing of the adolescent growth spurt, their noted variation in total energy and nutrient intake is perhaps not remarkable, but the relative contribution of fat is. I would, however, like to take issue with the conclusions of their last two paragraphs. While I would agree that weighing foods, except perhaps during initial instruction, is undesirable, I think that the British and Belgian data show that unless the diet is carefully directed an unsatisfactory choice will result. This direction must result in fairly major restrictions of choice and quantity of certain foods, which in turn implies some degree of 'measurement'.

However, unless obesity is developing, usually secondary to overenthusiastic insulin dosage, total energy intake can find its own level. Given the complexities of defining and measuring diabetic 'control' it is dangerous to be too dogmatic about its apparent relationship to degenerative angiopathy (Colwell, 1966). It may be that those whose diabetes proves to be relatively straight forward to control (one hesitates to use the word 'milder') are inherently less prone to develop vascular disease. This would show a spurious correlation between 'good control' and absence of retinopathy, whereas in fact they were both correlated with the nature of the metabolic disorder itself in that individual. It is improbable that juvenile diabetes is a uniform disorder, metabolically or genetically (Rimoin and Schimke, 1971). All these uncertainties should not, however, prevent our striving to attain euglycaemia, normal plasma lipids, and normal growth through careful attention to those factors we can control-insulin, diet, and exercise.

J. A. BIRKBECK,

Nutrition Department, University of Otago, Box 56, Dunedin, New Zealand.

\section{References}

Birkbeck, J. A., Truswell, A. S., and Thomas, B. J. (1976). Current practice in dietary management of diabetic children. Archives of Disease in Childhood, 51, 467-470.

Colwell, J. A. (1966). Effect of diabetic control on retinopathy. Diabetes, 15, 497-499. 
Dartois, A. M., and Lestradet, H. (1966). Food consumption of diabetic children at summer camps in France. Journal of the American Dietetic Association, 48, 32.

Dorchy, H., and Loeb, H. (1975). Valeur comparée de différents tests semi-quantitatifs pour la détermination de la glucosurie chez les diabétiques. Diabète et Métabolisme (Paris), 1, 87-90.

Dorchy, H., Mozin, M. J., and Loeb, H. (1975). Alimentation des enfants et adolescents diabétiques. Revue Médicale de Bruxelles, 31, 391-392.

Dorchy, H., Devroede, M., Toussaint, D., and Ernould, C. (1976). Angiofluoresceinic studies in infantile diabetic retinopathy. Proceedings of the 2nd Meeting of the International Study Group of Diabetes in Children and Adolescents (in press).

Drash, A. (1976). The control of diabetes mellitus. Is it achievable? Is it desirable? Journal of Pediatrics, 88, 1074-1076.

Ernould, C., Dorchy, H., Francois, B., Geussens, H., Mozin, M. J., and Loeb, H. (1973). Guide du Jeune Diabètique, p. 51. Revue Médicale de Liège, Liège.

Ernould, C., Devroede, M., Dorchy, H., and Loeb, H. (1976). Observation of growth in diabetic Belgian children and adolescents. The Balance of Diabetes in Juveniles. Ed. by Z. Laron. Karger, Basel (in press).

François, R. (1976). Réflexions sur le traitement du diabète infantile insulino-dépendant. Archives Françaises de Pédiatrie, 33, 425-430.

Lestradet, H., and Billaud, L. (1968). Complications dégénératives après 15 ans de diabète infantile. Presse Médicale, 76, 303-306.

Lestradet, H., Dartois, A. M., and Machinot, S. (1974). L'alimentation spontanée de l'enfant et de l'adolescent diabétiques traités par l'insuline. Annales de Pédiatrie, 21, 667-676.

Mozin, M. J., Dorchy, H., Ernould, C., Francois, B., Geussens, H., and Loeb, H. (1975). Observations concerning the spontaneous feeding of a group of diabetic adolescents in a vacation camp. Diabetes in Juveniles, $p$. 385. Modern Problems in Paediatrics, Vol. 12. Ed. by Z. Laron. Karger, Basel.

Mozin, M. J., Dorchy, H., Smets, P., Ernould, C., and Loeb, H. (1976). Spontaneous variations of intakes and balance of diabetes in diabetic adolescents. Acta Paediatrica Belgica (in press).

Rimoin, D. L., and Schimke, R. N. (1971). Genetic Disorders of the Endocrine Glands. Mosby, St. Louis.

\section{Achondrogenesis type I}

Sir,

We read with great interest the article by Lauder $e t$ al. (Archives, 1976, 51, 550). Their observation is correct in that their 2 cases are subvariants of achondrogenesis type I according to the McKusick classification.

We would like to point out that two distinct subtypes of that condition have already been described (Spranger et al., 1974; Yang et al., 1974, 1975). According to the criteria developed in our studies, the 2 cases reported by Lauder $e$ t al. should be classified into type I of lethal achondrogenesis (Yang et al., 1974, 1975, 1976, 1977), which is characterized by deficient cranial ossification, multiple rib fractures, shorter appendicular bones, sufficient cartilage matrix in the epiphyseal cartilage, higher incidence of familial occurrence, etc. Recently we have observed intracytoplasmic inclusion bodies in the resting chondrocytes (Yang et al., 1976, 1977). We suggest that Dr. Lauder and colleagues re-evaluate their histological sections of cartilage, which seem in the low magnification photomicrographs to contain several inclusions.

Type II lethal achondrogenesis differs roentgenographically and morphologically from type I. Grebe achondrogenesis, formerly type II, is nonlethal and appears to be an unrelated disease.

SHENG-S. YANG and JAY BERNSTEIN William Beaumont Hospital, Royal Oak, Michigan 48072,

$U S A$

Drs. Lauder and Ellis reply as follows:

We are grateful to Drs. Yang and Bernstein for their comments on our paper on achondrogenesis type I. At the time of preparation of our manuscript we were not aware of their recent paper (Yang et al., 1974) in which they report 2 cases, one of which exhibits similar clinical and pathological features to our own 2 cases. We agree with them that the available evidence seems to suggest two distinct forms of achondrogenesis type I. It remains our view that until the precise biochemical defects have been elucidated, no definitive classification is possible. This is also the view expressed by Wiedemann et al. (1974) whose collection of 6 cases is still the largest reported. The difficulties in attempting a classification based on 2 cases plus a review of previous studies are exemplified by the necessity for a 'readjustment of eponyms' which Yang et al. (1975) subsequently reported. As our paper points out, many of the studies are unsatisfactory in that no comments are made regarding the appearances in undecalcified material. The absense of adequate biochemical and histochemical data in these reports also makes distinction from conditions such as severe hypophosphatasia extemely difficult. It was also our aim to stress the importance of pulmonary hypoplasia as a cause of death in these infants.

We were most interested in the observation by Yang et al. (1976) of intracytoplasmic inclusion in resting chondrocytes. We have not had the opportunity to study their report or any illustrations of these bodies. We have not as yet been able to convince ourselves of the presence of inclusion bodies in our material.

\section{LAUDER and H. A. ELLIS Department of Histopathology, Royal Victoria Infirmary, Queen Victoria Road, Newcastle upon Tyne NEI $4 \mathrm{LP}$.}

\section{References}

Spranger, J. W., Langer, L. O., Jr., and Wiedemann, H.-R. (1974). Bone Dysplasias, p. 24. Saunders, Philadelphia.

Wiedemann, H. R., Remagen, W., Hienz, H. A., Gorlin, R. J., and Maroteaux, P. (1974). Achondrogenesis within the scope of connately manifested generalized skeletal dysplasias. Zeitschrift für Kinderheilkunde, 116, 223-225. 